Љиљана Марковић

Универзитет у Београду

https://doi.org/10.18485/ai_most.2017.ch10

Филолошки факултет

ljiljana.markovic@gmail.com

\title{
МОСТ УЂИ И ДРЕВНИ ЈАПАН
}

Мост Уђи представља врхунске естетске вредности Златног доба књижевности раног средњевековног Јапана. Лепота и симболизам су теме које обрађује јапанска поезија вековима, увек загледана у мост Уђи, у различитим годишњим добима. Мост Уђи је важна тема и у љубавној прози која описује пустоловине принца Генђија. Мост Уђи у јапанској древности представља везу између неба и земље, између овоземаљског, пролазног, и оностраног вечно лепог и узвишеног. Мост омогућава поезији и романескној прози периода Хеиан да додирне божанско и да читаоцима у 21. веку транспонује узвишеност дворске културе.

Кључне речи: Мост Уђи, књижевност древног Јапана, естетска начела, период Хеиан.

Други по величини град Кјото префектуре, Уђи је смештен на обалама истоимене реке на само десет километара југоисточно од древне престонице Јапана, града Кјотоа, који 794. године носи назив Хеиан-кио (срп. престоница спокоја и мира). Уђи се помиње већ 720. године у једној од најстаријих књига о историји Јапана - Нихон Шоки (Хронике Јайана). Педесети цар Јапана, цар Канму, као педесет други цар Сага, живели су у Уђију. За време Хеиан периода, због своје предивне природе овај град представља неку врсту уточишта (кизоку) за царску породицу и чланове аристократије. Он се у том периоду 
сматрао културним центром Јапана. На обалама Уђи реке граде се велелепне виле и храмови. Неке од ових грађевина данас се налазе на УНЕСКО-овој Листи светске баштине. Крајем IX века, на простору Уђија Мићинага, Фуђивара је изградио палату Уђи-ден (садашњи Бјодо-ин), која је 1994. године проглашна светском баштином од стране УНЕСКО-а као део Истиоријских сйоменика gревноі Кјойоа. Мост Уђи је једно од најзначајнијих обележја овог града и представља непресушан извор инспирације како прозних писаца, тако и песника који су оставили неизбрисив траг у књижевности древног Јапана.

\section{ИСТОРИЈА МОСТА УЂИ И ЮЕГОВО МЕСТО У ДРЕВНОЈ ЈАПАНСКОЈ КЬИЖЕВНОСТИ}

Мостови имају велики значај у јапанској култури и управо стога се налазе у сваком шинтоистичком светилишту у Јапану. Мост је и полазна и крајња тачка, те Хирошигеова збирка 東海道五十三次 (Tōkaidō Gojūsantsugi - Педесет три станице Токаида) почиње код моста Нихонбашија у Еду (Токију), а завршава се код Санђо Охашија у Кјоту. Мост Уђи ( 宇治橋) је саграђен 646. године и представља један од најстаријих мостова Јапана (поред Сета но Кара у Шиги и Јамасаки моста у Кјоту). У неколико наврата је порушен и наново изграђен. Мост који данас имамо прилике да видимо обновљен је 1996. године. Сведок је бурних историјских збивања, ратова и преврата, који су се одиграли 1180, 1184. и 1221. године, а нарочито се издваја као стратешки значајна тачка током битке која се водила између Царског двора и ратника-монаха планине Хиеи, када је 1236. године мост порушен како би се спречило напредовање ратника-монаха ка царској престоници - Кјотоу. Осим тога, мост Уђи је имао веома важну улогу као прва станица дугачких каравана, који су преносили 
уђи чај током Едо, оносно Токугава периода до територије данашњег Токија (Токио је у том периоду носио назив Едо, све до пада Токугава шогуната 1868. године).

Мост представља чест мотив у светској књижевности и носи различита значења у зависности од културе и обичаја земље у којој се налази. Мост Уђи приближава поезију и романескну прозу периода Хеиан божанском, а читаоцима у 21. веку транспонује узвишеност дворске културе тог периода. Као књижевни мотив посебно је присутан у делима која припадају Златном добу књижевности раног средњевековног Јапана. Лепота и симболизам су теме које обрађује јапанска поезија, која је вековима загледана у мост Уђи у различитим годишњим добима. Од великих књижевних дела у којима мост Уђи има значајно место, посебно се издвајају Прича о Генђију и (Шин) Кокин Вакашу, царска антологија јапанске вака поезије.

\section{МОСТ УЂИ И ПРИЧА О ГЕНЂИЈУ}

Мост Уђи представља важан мотив у љубавној прози која описује пустоловине принца Генђија. Заправо, човек који је послужио као модел за Генђи моноїайари (Причу о Генђију) - Сага Генђи живео је у Уђију, те се радња последњих десет поглавља романа одвија управо на обалама реке Уђи. Књижевница Мурасаки Шикибу ствара дело Прича о Генђију почетком 11. века. Оно чини прекретницу у јапанској књижевности, имајући у виду да представља први роман са развијеном радњом и књижевним ликовима. Уколико се изузму бајке и неколицина мемоара, поезија је била преовлађујући вид књижевно-уметничког изражавања у древном Јапану, те се пре настанка овог романа књижевна продукција у Јапану углавном сводила на збирке песама. Као први роман јапанске књижевности, ово дело привлачи велику пажњу 
књижевних критичара од свог настанка па све до данас.

Радња романа подељена је у три целине, које су изложене у педесет и четири засебна поглавља. Првих тридесет и три поглавља прате судбину Хикару Генђија - од његовог рођења до тренутка када је био на врхунцу моћи. Она дају увид у живот на двору древног Јапана, односно у један затворен, елитистички, аристократски свет који је у свом центру имао цара. Анализа друштвеног поретка у Причи о Генђију води до закључка да се популација древног Јапана јасно делила на оне који су рођени са привилегијама и оне на које се гледало као на нижу врсту. Чланови аристократије своје слободно време проводе читајући збирке песама, слушајући музику, занимајући се за калиграфију и уживајући у природи. Стога је и тематика прве целине Приче о Генђију превасходно љубавна. Другу целину чини осам поглавља у којима писац говори о паду и пропадању принца Генђија. Тринаест поглавља треће целине описују живот Генђијевог сина Каоруа, при чему је место радње Десет Уђи поглавља (宇治十帖 Уђи-ђуђо) измештено из царске престонице - града Кјото у древни јапански град Уђи.

Мотив моста је пре свега присутан у последњој целини Приче о Генђију, те тако прво поглавље Десей Уђи

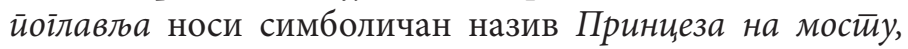
док је последње поглавље ове целине (а уједно и целог

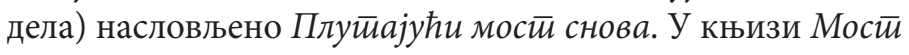
снова: йоетичка Приче о Генђију, Харуо Ширане наглашава да је физички простор у поглављу Принцеза на мосӣ $y$ „на симболичан начин подељен између планинског села које Коару посећује (...) и престонице, која представља његов дом. Турбулентна река, тиха планина, дуг пут, густе измаглице и рустично имање јасно издвајају село Уђи од префињене, богате атмосфере на двору." Shirane, H. (1987: 186) У том контексту, мост има метафоричну функцију преласка из раскошног, бучног простора двора у простор 
где преовлађују природне лепоте, мир, спокој и религиозна осећања. Осим тога, мост симболизује и прелазак из једне генерације у другу, са оца на сина - принца Генђија на његовог сина Коаруа и сведочи о променама које су задесиле друштво двора древног Јапана, које све чешће тражи уточиште од царске престонице у природним лепотама Уђи реке и долине.

Атмосфера поглавља Принцеза на мосӣу уноси меланхоличне ноте у ток приповедања, које се пре свега огледају у смењивању годишњих доба и преласка из пролећа у јесен. Мотив моста говори и о овој дихотомији годишњих доба, односно преласку из веселе, готово пролећне атмосфере каква је владала на јапанском двору у време принца Генђија, ка јесењим, мрачнијим и сетнијим сценама какве проналазимо у Десети Уђи йоилавља. Оваква атмосфера се може повезати и са сличношћу која постоји између речи Уђи и јапанске речи за суморно и мрачно, на коју у IX веку указује будистички монах и песник Кисен следећим стиховима:

$$
\begin{aligned}
& \text { „На јуїоисӣоку їлавної їраgа } \\
& \text { Живим у мојој сламнайној колиби. } \\
& \text { Свети је мрачан, кажу, } \\
& \text { Суморан као име ових Уђи брgа. "I }
\end{aligned}
$$

Тегобну атмосферу Десей Уђи йоїлавль можда најбоље осликава уводна реченица четрдесет и седмог поглавља, која гласи: „У јесен, док су Уђи принцезе припремале годишњицу очеве смрти, ветрови и воде које су годинама познавале изгледали су хладнији и усамљенији

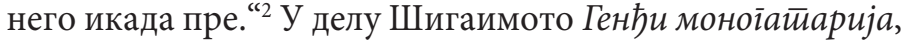

Стихове са енглеског превела: проф. др Љиљана Марковић.

2 Прича о Генђију. Преузето ca: https://ebooks.adelaide.edu.au/m/ murasaki-shikibu/tale-of-genji/chapter47.html, приступљено: 21.07.2017. Превела са енглеског: проф. др Љиљана Марковић. 
ауторка наводи да је зими Уђи јако хладно место и да је на реци и планинама све залеђено, те gа кою не жели ga хоgа... Али ја ћу gоћи са gруіе сирране реке gа йе вияим (つ らら閉ぢ駒ふみしだく山川をしるべしがてらまづや渡 らむ). Као израз чежње и туге због неостварене љубави, Каору се у сличном меланхолично-сетном тону обраћа својој вољеној Укифуне. Он описује пределе долине Уђи и повезује тужна љубавна осећања са природним непогодама какве су честе у Уђи области следећим речима:

$$
\begin{aligned}
& \text { „У } \overline{и о м ~ с е л у ~ У ђ и ~} \\
& \text { ige воgе нейрекияно бујају } \\
& \text { Питиам се како си, } \\
& \text { каgа у бескрајној киши } \\
& \text { и срие и небо йостиају мрачни." }
\end{aligned}
$$

У последњем поглављу романа - Плуйајући мости снова, мотив моста има готово метафизичку функцију. Наиме, ово поглавље романа Прича о Генђију говори о принцези Укифуне као часној сестри, која се на тај начин одваја од материјалног света и тужних љубавних прича које су обележиле њен живот. У том погледу, може се рећи да се роман завршава одустајањем од свега што је чулно и опипљиво и прелази се у свет духовног и метафизичког. И сама чињеница да је крај овог и за данашње појмове подужег романа поприлично неодређен сведочи о томе да и сам живот представља неочекиван прелазак из сфере материјалног у духовно. Мост као књижевни мотив представља спону која спаја неспојиво и води ка метафизичком простору.

До данас је написан велики број књига и студија које за циљ имају да појасне функције моста у роману Генћи моно-

3 Seidensticker, Edward G. The Tale of Genji (trans.). New York: Alfred A. Knolf, 1992. Преузето ca: https://intojapanwaraku. com/EN/culture/20170214/6809/p6, приступљено: 25.07.2017. Стихове са енглеског превела: Љиљана Марковић. 
іат̄ари. Међутим, у којој мери су последњих десет поглавља једног од најстаријих и најлепших љубавних прича на свету од значаја за целокупну историју јапанске књижевности, можда најбоље сведочи чињеница да је у Уђију 1998. године отворен Музеј Приче о Генђију где су верно репродуковане сцене Десети Уђи йоїлавља уз помоћ слика, путака-модела и сценографије. Како би својим посетиоцима у потпуности дочарали Уђи йоілављь, снимљен је и кратки филм који се приказује као додатак тематским изложбама.

\section{МОСТ УЂИ И (ШИН) КОКИН ВАКАШУ}

Мост Уђи често је био и инспирација песницима древног Јапана. Велики број песама у којима се помиње мост Уђи могу се пронаћи у царским антологијама вака песама (класичне јапанске поезије), као што је прва збирка древних и модерних јапанских песама Кокин Вакашу (古今和 歌集) за коју се још користи скраћен назив Кокиншу (古 今集). Идејни творац ове збирке је био цар Уда. Међутим, збирку по први пут објављује његов син цар Даиго највероватније 905. године. Кокиншу броји 1.111 песама које су распоређене у 20 књига, у зависности од тематике којом се баве. Шест засебних књига посвећено је певању о годишњим добима, пет љубави, а преостале књиге се баве различитим темама, као што су: честитања, растајања, путовања, оплакивања, итд. Иако уводна реченица предговора овој антологији гласи: Јайанска йоезија узима за своје семе тьуско срие и самим тим наглашава да ова збирка има универзалан карактер, те да су емоције исказане у њој заједничке читавом људском роду, песме начелно говоре о симболима који су јединствени за Јапан. Један од тих симбола јесте и мост Уђи.

Аутори песама које чине саставни део Кокин Вакашу антологије су углавном остали непознати - око 450 песама 
је непотписано, док је преостали број песама писало чак 130 песника. Имајући у виду велики број аутора, песме се могу поделити у најмање три различита временска периода. Први период траје од почетка до средине IX века и њега одликује анонимност аутора. Други период обухвата песме шест великана јапанске поезије написане средином IX века, док трећи траје све до почетка X века и укључује и песме уредника антологије и њихових савременика. Најпознатији песници антологије објављене 905. године су: Оно но Комачи, Фуђивара но Окиказе и Аривара но Нирихира.

Уз мотив Уђи моста често се везује и лик Хашихиме Принцезе Уђи моста: хаши (橋 - мост) и химе (姫 - принцеза). Прво поглавље целине Десей Уђи йоілтавља романа Прича о Генђију је заправо насловљено њеним именом. Хашихиме је у књижевности Хеиан периода иницијално представљена као усамљена жена која с нестрпљењем чека посету свог неверног љубавника. Временом, она у књижевности поприма одлике демона, жене која луди од љубоморе и постаје демонско створење. Претпоставља се да се повод за настајање овог књижевног лика може пронаћи у причи о племкињи Рокуђо, коју приповеда главни јунак Приче о Генђију. Након што обузета љубомором постаје демон - икисуgама - биће чији дух је још за живота у стању да напусти тело и прогони друге, Рокуђо, Генђијева некадашња љубавница, изазива смрт Генђијеве трудне жене Аои но Уе, а самим тим и његовог детета. Након своје смрти, Рокуђо постаје онрио - дух освете и наставља да прогони Генђијеве љубавнице.

Будући да се везује за мотив Уђи моста, Хашихиме је на сликама често представљена као демонско створење које излази из воде. У оквиру Кокин Вакашу антологије, у песми анонимног аутора помиње се лик Хашихиме Принцезе Уђи моста. Ова песма гласи: 


\section{„На хлаяној йоgлози разастиирући своју хальину gа ли ће ме и ове ноћи чекайи (Хашихиме) Приниеза Уђи мостиа?"“}

(Bialock, 1994: 205)

Кокин Вакашу је само прва у низу царска антологија јапанске вака поезије, које су објављиване све до 1439. године. Осма антологија по реду, Шин Кокин Вакаму, односно Шин Кокиншу - Нова збирка древних и модерних песама, садржи неке од најлепших песама у којима се спомиње мост Уђи. Један од аутора који је умешно користио овај мотив јесте Фуђивара но Теика, јапански песник, прозни писац, критичар и један од највећих мајстора вака поезије. Теика је истовремено био и главни уредник осме антологије царске јапанске поезије, а од његових четрдесет и шест песама које су објављене у антологији Шин Кокин Вакашу 1205. године, наилазимо на следећу песму која је јасно инспирисана мостом Уђи и ликом Хашихиме:

$$
\begin{gathered}
\text { Колико је хладно! } \\
\text { чекати уморну јесењу ноћ } \\
\text { која постаје све дубља како ветар дува } \\
\text { Она шири месечеву светлост } \\
\text { Принцеза Уђи моста. } \\
\text { (Bialock, 1994: 205) }
\end{gathered}
$$$$
* * * * * *
$$

Мост Уђи у јапанској древности представља везу између неба и земље, између овоземаљског, пролазног, и оностраног, вечно лепог и узвишеног. Будући да има зна-

$4 \quad$ Bialock, David T. (1994), "Voice, Text, and the Question of Poetic Borrowing in Late Classical Japanese Poetry", Harvard Journal of Asiatic Studies, Harvard-Yenching Institute, 54 (1), стр. 205.

5 Bialock, David T. (1994), "Voice, Text, and the Question of Poetic Borrowing in Late Classical Japanese Poetry", Harvard Journal of Asiatic Studies, Harvard-Yenching Institute, 54 (1), стр. 205. 
чајно место у највећим делима Златног доба књижевности раног средњевековног Јапана, овај мост представља један од најважнијих књижевних мотива у јапанској поезији и прози и као такав завређује да буде предмет исцрпних научних студија о књижевности древног Јапана.

\section{Литература:}

Bargen, D. G. A woman's weapon: spirit possession in the Tale of Genji (наслов италиком). University od Hawaii Press, 1997.

Bialock, David T. Voice, Text, and the Question of Poetic Borrowing in Late Classical Japanese Poetry. Harvard Journal of Asiatic Studies, Harvard-Yenching Institute, 1994. 54.

Carter, S. D. Traditional Japanese poetry: an anthology. Stanford University Press, 1991.

Field, N. The Splendor of Longing in the Tale of Genji. No. 21. University of Michigan Center for, 2001.

Harries, P. T. Personal Poetry Collections. Teir Origin and Development Trough the Heian Period. Monumenta Nipponica. 1980. 299-317.

Markovic, Ljiljana, et al. Japan u praskozorje modernizacije. Beograd: Filološki fakultet, Beograd: Čugura print, 2016. 150.

Markovic, Ljiljana, Du Chengan. Književnost središnjeg carstva. Beograd: Filološki fakultet, 1998. 160.

Markovic, Ljiljana, i Marina Jovic. Istorija civilizacije Japana. Beograd: Filološki fakultet, 2002. 277.

Markovic, Ljiljana. Civilizacija Japana u srednjem veku. Beograd: Filološki fakultet, 2007. 315.

Night, B. Kokin wakash $\bar{u}$ and the Court Style in Japanese Classical Poetry. 1985.

Seidensticker, Edward G. Te Tale of Genji. New York: Alfred A. Knolf, 1992. Veb. 25.07.2017.

Shikibu, M. The tale of Genji. Penguin, 2003

Shirane, H. The Bridge of Dreams: A Poetics of The Tale of Genji. Stanford University Press, 1987.

Tyler, R. The tale of Genji. Vol. 1. New York: Viking, 2001.

Waley, A. The Tale of Genji. Boston and New York: Houghton Mifin, 1935. 


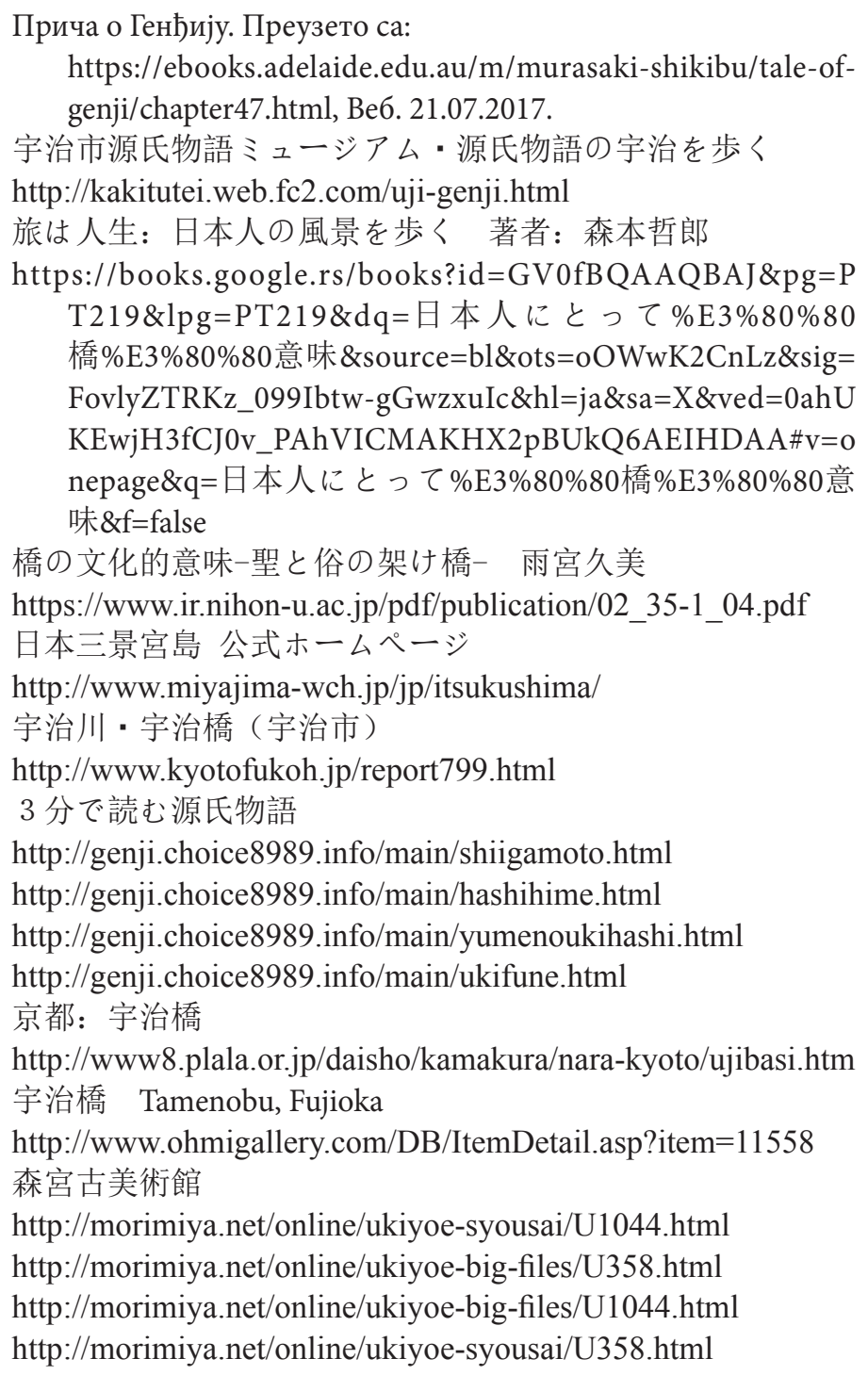


Ljiljana Marković

\section{THE UJI BRIDGE AND ANCIENT JAPAN}

The Uji Bridge represents the supreme aesthetic values of the Golden Age of Early Medieval Japan's literature. Japanese poetry treats the themes of beauty and symbolism for centuries, by constantly gazing at the Uji Bridge throughout different seasons. The Uji Bridge is also an important theme in love prose that describes the adventures of Prince Genji. Within the Japanese antiquity, the Uji Bridge represents the link between heaven and earth, between the mundane, transient, and the eternally beautiful and sublime beyond. The bridge has enabled the poetry and novelistic prose of Heian period to reach the divine, and has transposed the sublime court culture to the readers in the $21^{\text {st }}$ century.

Key words: Uji Bridge, literature of ancient Japan, aesthetic principles, Heian period 